\title{
Public Perception towards Police Corruption: A Case Study of Tehsil Takht Bhai
}

\author{
* Muhammad Zahid, Lecturer (Corresponding Author) \\ ** Rahman Hussain, PhD Scholar \\ **** Hazrat Bilal, MA Sociology
}

\begin{abstract}
Throughout the world, the department of police has been established for enforcing the law, protecting the life and property of the people, and ensuring peace. Police play a vital role in maintaining law and order in the society as well as controlling crimes and their services are considered as good, but police corruption has also occurred throughout history and therefore it is by no means a new phenomenon. The issue of corruption in police in terms of lodging first information report (FIR), during investigation and detention, calls for immediate attention from the researchers because it negatively affects justice delivery in society. The current study was conducted in Tehsil Takht Bhai, of district Mardan, Khyber Pakhtunkhwa Pakistan, which examined the perception of the general public, drivers, elected representatives, lawyers, past prisoners, and the police tout about police corruption. The study was qualitative specifically based on thematic research design. A stratified purposive sampling technique has been utilized, while the Focus Group Discussions (FGDs) were used as a tool for collecting primary data. Further, focus group discussions were elaborated narrated and linked with the literature (thematic analysis) to extract findings. Research findings show that corruption is prevalent in police at different levels, and it is suggested that media campaigns, public awareness, and legislation about corruption need to be implemented to control corruption in the police.
\end{abstract}

Keywords: $\quad$ Police, Corruption, Bribery, Public Perception

Introduction

Police is a formal public department established to ensure peace, enforce the law, maintain social order, and control crime (More \& Miller: 2015). Throughout the world, the services of police are accepted to be a social good (Ayling: 2007). Generally, it is the wish of most of the people to live in a peaceful and safe environment. The purpose of the police is to be visible in the community, to serve the people, and should be easily accessible to the citizens when their services are required (Wang: 2015). According to Robert Mark who was commissioner of the Metropolitan police "A good police force is the one that catches more criminals than it employs" (Woodland: 2015).It is expected from the police that they will follow the rule of law and should be accountable for their decisions and actions (Punch: 2000). Various research studies have pointed out that the citizens expect the police that they will respond when their services are needed fairly and impartially (Eck \& Rosenbaum: 1994).

Like other countries, in Pakistan, all the provinces have their police varying in size from each other. The Police force is developed to protect the people and ensure peace in the entire vicinity. The same is the case of Khyber Pakhtunkhwa where the police force is structured to protect all parts of the provinces from criminal activities of the criminals as well to fight against terrorism in the province. For successful consequences, the police must be professional and they will not abuse their power and authority. Any behavior that goes beyond the authority of someone can be called corruption (Javaid: 2010). Corruption refers to Acts barred by law of the land, or ethical standard of the society (Withrow\& Dailey: 2004). Corruption is the abuse and misuse of public resources for personal gain and benefits (Johnston: 2005). The word police corruption leads to explain various actions such as bribery, violence, brutality, favoritism, and nepotism (Newburn: 1999).

\footnotetext{
* Department of Sociology, Abdul Wali Khan University Mardan

** Department of Sociology, University of Peshawar

*** Department of Sociology, Abdul Wali Khan University Mardan
} 
Like other provinces, Khyber Pakhtunkhwa police are also alleged that they are involved in corrupt practices that affect their performance (Farhatullah et.al: 2015). Many police officers are removed from the services because of their involvement in corruption (The Daily Dawn: 2015). Both petty and grand corruption is prevalent. The lower rank police personnel are involved in petty corruption. The high level and senior police officers are mostly involved in grand corruption as the case of former police chief who was arrested and convicted for receiving Rs. 2031.25 million from a contractor in the procurement of weapons for the department (Ahmad: 2015). Because of these corrupt scandals, the general public perceives police as one of the most corrupt departments.

There are several theories presented by scholars that highlight factors contributing to the public perception of corruption. The arguably theory explains the perception of corruption related to economic factors, personal economic status, and country economic condition. If the economy of a country is blooming, the people will have an optimistic view of country political institutions. On the other hand, if the country economy is weak, the people will be less tolerant regarding public officials of the country. Similarly, the available literature also highlights that the stability of the regime and the level of democratization affect degrees of perceived corruption (Seligson: 2006).

\section{Literature Review}

Corruption is a Latin word which means to pollute or spoil or abuse, depending on the context. It is the unlawful use of power and authority. Any act that surpasses the limit of power and authority vested to him/her can be referred to as corruption (Javid: 2010). It is the misuse of power for own benefits through accepting bribes, embezzlement of funds, and extortion (Quah: 2011). It is a behavior which deviates a person from his role and responsibilities. Corruption pollutes human life and brings a bad reputation to the country. It is almost the problem of every country and ill effects prevail in developing as well as in developed countries.

Police corruption refers to the act of an officer that is against his duty and is done for personal gain or promise of such gains (Punch: 2009). It is the exploitation of position which leads to the break of trust which the public has on the police. Police and police corruption go side by side and when there are police there will be corruption (Punch: 2009). This is a worldwide problem which exists globally in various forms. In developing countries police corruption is a matter of routine and everyone becomes victims who deal with the police (Farhatulla et.al: 2015).

The stories of police corruption in Pakistan are regularly highlighted by print and electronic media. Police corruption is visible and they can be seen on roads taking bribes from drivers. Because of corruption, the reputation of Police in Pakistan is poor and they are avoided by the public to get their services (Farhatullah et.al: 2015). In Pakistan, the public perceives the police as corrupt and dishonest. According to Transparency International, "Police remains the most corrupt sector according to the perceptions of Pakistanis (Transparency International: 2010). Mostly the rural people are targeted by the police, as they are unaware of police duty, and thus police demand for bribes when they register First Information Report (FIR).

Police behavior with common people can be well understood by referring to the term "Thana Culture", which is a name used for police station; highlights the abuses of power and authority by the police in the police station. On the name of suspects, unlawful search operations are carried out by the police, arrest innocent people, threaten and beat them, and are released after paying bribes (Shoro: 2017). According to the "Global corruption barometer 2010" by Transparency International; "In Pakistan, the police department is the most corrupt department" (Transparency International: 2010). Police have the power to ask and investigate the citizens and this power made them corrupt as they use this power for personal gains.

\section{Study Rationale}

Corruption is a burning issue in Pakistan. Newspapers and electronic media reports highlight that corruption is increasing and no public-sector institution is immune from this menace. But the general perception is that corruption in the police department is rampant. According to the Transparency International-Pakistan report titled "Police remains the most corrupt sector according to the perceptions of Pakistanis" (Transparency International: 2010). Corruption is done by the police while performing their daily routine duty. They use violence to achieve their bureaucratic aims and while interacting with citizens make the environment for greasing their palms (West \& Green: 2002). They afraid of the police and mostly do not report cases to police and when report a case to the police, 
police demand bribes from them. Thus, these poor people are at the mercy of corrupt police officers (World Development Report: 2006).

The police department is one of the important departments to ensure peace and maintain law and order for which they are given the power to arrest and carry out search operations in any locality. But some of the police personals misuse this power and authority which is granted to them by the state. Many observers criticize police and a common perception among the people is that the police take bribes on roads and in police stations. According to Transparency International, in police stations, the police extort money from the citizens and the ill-gotten money is shared among the senior officers (Transparency International: 2002). The politicians use the police for protecting their interests and arrest and release the arrestees on the direction of politicians (The Daily Dawn: 2012). The public doesn't trust police due to their obvious corrupt nature and this has undermined the reputation of the police department (Walker et.al: 2016).

Pakistan established their police system, but unfortunately, since after independence of Pakistan police failed to serve the people (Jackson, et.al. 2009). In Pakistan, here are class differences and the police serving the influential (Arain: 2009). After independence in Pakistan, the "Thana Culture" has not been changed and still the citizens consider police stations as a place of horror. While dealing with policemen, one cannot expect good behavior from them. In custody the detainees are tortured which is the only tool used for investigation (Siddiqui: 2001).

Thus, the police have spoiled the name, fame, and reputation of the department because of corruption which has widened the gap between the police and community which results in a lack of cooperation of the community with police. The police force cannot be successful unless the community cooperate with them (Miller, Hess \& Orthmann: 2017). The relation between the community and police has remained an elusive phenomenon throughout the world and for a good police-community working relationship, a good public perception towards police is very essential. (Mbuba: 2010). This study is conducted to know about how the police are perceived by the community, to identify these gaps and give recommendations so that the gap can be bridged.

\section{Objectives of the Study}

Following are the objectives of the study

1. To know about public perception regarding nature and form of corruption in the police department

2. To inquire about public perception about the consequences of police corruption.

\section{Methodology and Procedure}

The current study has been conducted to know public perception towards police corruption and to what extent the public is affected by the corruption of Police. The study was conducted in Tehsil Takht Bhai of district Mardan in 2018, and information was collected from those respondents who were being victimized by the police and they knew about police corruption.

The study was qualitative and Focus group discussion was used as tools of data collection. Stratified purposive sampling was used and research participants were invited in a group of 8-10 participants of different categories included general public, drivers, elected representatives, lawyers, past prisoners, police touts, and those who had any contact with police in last one year. A total of 4 Focus Group discussions were conducted and primary data was collected from the respondents which served the purpose. Further, for qualitative data analyses, the interpretative approach was used as recommended by Miles and Huberman (Berg: 2001) and transcription of the interviews was done and the collected data was converted into notes and identified a set of relevant categories and themes. Finally, the collected data was presented in such a way that the main theme was brought to limelight.

\section{Results and Discussions}

\section{The Culture of Bribery}

According to the respondents, it is difficult to get the services of the police without paying bribes. Those who interact with police will have to pay bribes. The police have a lot of opportunities for taking bribes from the citizens. They take bribes when the complainant comes to the police station for registration of FIR, from those who are arrested and target those who visit detainees when they are in the custody of the police at the police stations. They use their uniform as a tool for making money by extorting law-abiding citizens and even extort money from those who are more vulnerable (Haugen \& Boutros: 2014). 
According to a respondent when a crime is committed, the police arrest many citizens on the name of suspects, and then they are released after paying bribes to the police. Those who do not pay bribes are kept in custody for several days. This is an illegal act as the article 10 of the constitution of Pakistan states that "...Every person who is arrested by the police and detained in custody shall be produced before a Magistrate within twenty-four hours of such arrest... and no such person shall be detained in custody beyond the said period without the authority of a magistrate..." (Rabia: 2013). According to the respondents to extort money, the detainees are tortured very harshly. This was also revealed by the finding of a study conducted by Waseem Haider that $92 \%$ of detainees were physically tortured by the police (Rabia: 2013).

The police are bribed to get their support as revealed by Kim et.al "the offenders pay bribes to police for whom they are granted relief" (Kim et. al: 2013). The respondents also shared that investigation is a rich source for the police through which they extort money. They shared that bribes are received by the investigation officers and thus favor the party who bribes the police. The police also change the investigation report in favor of the payers. It is in the hands of police to prove guilty as innocent and innocent as guilty through investigation reports which they do for money.

\section{Favoritism and Nepotism}

In the police department, favoritism is a type of business that is done by the police. According to respondents, in theft cases, the complaints of common people are not easily registered until the influentials of the area intervene. The respondents shared that arrestees involved in minor crimes are released on the instruction of influentials. The public is not equally served. This can be easily observed while visiting a police station; those who are influential or having any relative in the police, their work is done in minutes, but on the other hand, common people are not served. The common people are feared and serve the interest of influential and wealthy people (Perito and Parvez: 2014). The responded shared that citizens are not equally treated by the police and the influential are favored in every matter, which has lowered the trust of the common people on police.

\section{Protection of Illegal Activities}

As pointed by Salinger, the police illegally protect drug dealers, prostitutes, and other organized offenders (Salinger: 2005). This is often done by the police for personal gains. The study found that illegal activities are protected by the police for personal gains. The public is of the view that police protect individuals and groups involved in criminal enterprises. No one can establish an illegal business without the will of the police. Police know everything but because of the benefits received from the owners, they shut their eyes to the wrong ones. This is the reason that despite many check posts, daily hundreds of Non-Custom Paid (NCP) vehicles are transported to the Malakand division form the border of Afghanistan illegally. According to another respondent Prostitutes and prostitution centers are known to the police but they are not arrested as the police are benefited. The respondents also shared that auto theft is also protected by the police in exchange for money paid to them.

According to the public, it is difficult for anyone to carry out illegal activities without the will of the police. Police are aware and those involved in illegal businesses, owners of the brothel, criminals, and robbers are known to the police but they are not arrested by the police as they give those benefits.

\section{Corruption by Traffic Police}

The traffic police serve on roads for traffic regulation. They charge the drivers when they violate traffic rules. According to the drivers, bribes are received by traffic police as a routine. One of the drivers shared that by violating traffic laws, the fine can be avoided by paying bribes to the traffic police. The traffic police also take monthly fixed money from the drivers and then they are not charged throughout the month on violation of traffic laws.

It is common in developing countries where traffic police extort bribes from drivers (Kumssa: 2015) Bribes ate received by traffic police even in developed countries. According to a study conducted on bribery in Russia, perceived levels of bribery among the police, the traffic police are leaders followed by regular police. (Semukhina \& Reynolds: 2013).

\section{Consequences of Police Corruption}

The public perceives the negative consequences of police corruption. According to them, police corruption increases crime in society as the criminal are encouraged that if they are caught, they will be released by the police. Vadackumchery (1998) also believes that the major cause of increasing crime in 
society is police corruption. The main aim of the police department is to control crime but when the police indulge in corruption the rate of crime will be increased. According to Syed (1997) when criminals have the chance to escape from the law, if caught in illegal activities or have a chance to receive lighter punishment than the crime they have committed, they will be more likely to engage in crime.

The respondents shared that the police department has a bad reputation because of corruption and because of police corrupt practices; we don't trust the police. Thus, corruption widens the gap between police and the public. Police are not trusted because of corruption (Prenzler: 2009). Those societies are more secure where people have trust in the police (Hinry\&Smith: 2007). To bring the public and police together, the problem of corruption must be tackled.

\section{Conclusion}

The police role is to provide protection to the public, maintain peace and alleviate crimes from society. The cooperation of the public with the police plays an important role. But the public perceives police as corrupt and this filth of corruption has ruined the police department and deviated them from their actual role to be performed. Because of corruption, the people feel fear and are reluctant to interact with the police and to get their help when needed. According to the perception of the public, the police receive bribes from the arrestees, they do corruption in investigation, protect illegal activities, indulged in favoritism and nepotism and are involved in illegal arrest and detention of the citizens. Similarly, police corruption has negative consequences. It increases the crime rate and brings a bad reputation to the police department. Corruption widens the gap between citizens and the police which weakens the strength of the police department. Citizens will not be ready to cooperate with the police when they have no trust in the police. The citizens must be realized that they are being treated with great respect in day to day interaction with police.

\section{Recommendations}

1. Media campaigns should be launched to create public awareness that the police department is for the public and they are not required to pay them bribes for getting their services.

2. Police should be encouraged to face political pressure and they should not be transferred on the saying of politicians.

3. Police should be made accountable for their corrupt actions. Punishment should be given to those who take bribes.

4. Loopholes available for police corruption should be blocked

5. With the existing anti-corruption measures an independent commission for controlling police corruption should be established.

\section{References}

Arain, S.M. (2014).Women Police Unfurled in Pakistan: Respective, Status, and Prospective. Hyderabad: A House of Knowledge. P 96.

Ayling, J. (2007). Contractualism and Policing in the Public Interest. Accession Dec 5, 2017, athttp://dspace.flinders.edu.au/dspace/bitstream/2328/1825/4/Ayling\%20jaa.pdf.

Berg, B.L. (2001).Qualitative research methods for the social sciences. Boston: Allyn and Bacon. P 238.

Chaudhry, R. (2013). Policing, Custodial Torture and Human Rights: Designing a Policy Framework for Pakistan. Lahore: Cross Media.

Eck, J. E., \& Rosenbaum, D. P. ed. (1994). The New Police Order: Effectiveness, Equity, and Efficiency in Community Policing. California: Sage Publication. Pp. 3-26.

Farhat, U., Akhunzada, Z.U. \& Sajid, I.A. (2015). Crossing the line: Perception about police corruption in Khyber Pakhtunkhwa, Pakistan. Pakistan Journal of Criminology, Vol 7, No 4. Oct 2015 PP 103-115.

Haugen, G.A., \& Boutros, V. (2014). The Locust Effect: Why the End of Poverty Requires the End of Violence. New York: Oxford University Press. P 87

Henry, A., \& Smith, D.J. (2007).Transformation of Policing. Hampshire: Ashgate Publishing Limited) P 300.

Jackson, J., Bradford, B., Hohl, K.,\& Farrall, S. (2009). Does the fear of crime erode public confidence in policing? Policing. PP100-111. 
Javaid, U. (2010). Corruption and its Deep Impact on Good Governance in Pakistan. Pakistan Economic and Social Review, 48(1), 123-134 (summer 2010).

Javaid, U. (2010). Corruption and its Deep Impact on Good Governance in Pakistan. Pakistan Economic and Social Review, 48(1), 123-134 (summer 2010)

Johnston, M. (2005). The Syndrome of Corruption: Wealth, Power, and democracy. New York: Cambridge University Press. P12.

Kim ET. al. (2013). Relation between Corruption and Human Rights in North Korea. Seoul: Korea Institute for National Unification. PP 24-25

Kumssa, A. (2015). Police Corruption: A perspective on its Nature and Control. Donnish Journal of Political Science and International Relations Vol 1(1) pp. 001-008 March, 2015.

Mbuba, J.M. (2010). Attitudes Toward the Police: The Significance of Race and Other Factors Among College Students. Journal of Ethnicity in Criminal Justice, 8:3, 201215, DOI: 10.1080 /15377938.2010.502846

Miller, L.S., Hess, K.M., \& Orthmann, C.H. (2017). Community Policing: Partnership for Problem Solving. Boston: Cengage Learning. P 71.

More, H.W., \& Miller, L.S. (2015). Effective Police Supervision. Waltham: Elsevier. P 375.

Newburn, T. (1999). Understanding and preventing police corruption: lessons from the literature policing and Reducing Crime Unit Research. Police research series, paper 110. Development and Statistics Directorate 50 Queen Annes Gate London SW1H9AT.

Perito, R., \& Parvez T. (2014).A Counter-Terrorism Role for Pakistani's Police Stations. Published by United States Institute of Peace. P2.

Prenzler, T. (2009).Police Corruption, Preventing Misconduct, and Maintaining Integrity. Boca Raton: CRC Press. P 19

Punch, M. (2000). Police Corruption and its Prevention. European Journal on Criminal Policy and Research. PP 301-324.

Punch, M. (2009). Police Corruption: Deviance, Accountability, and Reform in Policing. New York: Routledge.

Quah, J.S.T. (2011).Curbing Corruption in Asian Countries: An Impossible Dream? Bingley: Emerald Group Publishing Ltd. P 10.

Salinger, L.M. (2005). Encyclopedia of White-Collar \& Corporate Crime. Vol No 1. Thousand Oaks: Sage Publication. P 619

Seligson\&Michael. (2006). The measurement and impact of corruption victimization: Survey evidence from Latin America". World Development, V. 34, n. 2, PP. 381-404.

Semukhina, O.B., \& Reynolds K.M. (2013).Understanding the modern Russian police. Boca Raton: CRC Press. P 217.

Shoro, S. (2017). Honor Killing in The Second Decade of the 21st Century. Cambridge: Cambridge Scholars Publishing. P 177.

Siddiqui, T.A. (2001).Towards Good Governance. Karachi: Mehran Printers. PP 42-43.

Syed, T. (1997).Not Victimless: Understanding the Harmful Effects of Police Corruption. Accessed on Sep 07, 2017, at http://www.csvr.org.za/wits/papers/papsyed.htm.

The Daily Dawn, Jul 8, 2015.

The Daily Dawn, Sep 11, 2015

The Daily Dawn, Sep 29, 2012

Transparency International (2002). "Nature and extent of corruption in the Public sector. P 28.

Transparency International (2010).Global Corruption Barometer. P19.

Transparency International-Pakistan Report (2010). National Corruption Perception Survey. P15.

Vadackumchery, J. (1998).Crime Police and Correction. New Delhi: APH Publishing Corporation. P 9.

Walker, S. (2016).The Color of Justice: Race, Ethnicity, and Crime in America. New York: Cengage Learning. P 179.

Wang, X. (2015). Empowerment on Chinese Police Forces Role in Social Service. Berlin: Springer. P 20.

West, D.J., \& Green, R. (2002). Sociolegal Control of Homosexuality: A Multi-Nation Comparison. New York: Kluwer Academic Publishers. 
Withrow, B.L., \& Dailey, J.D. (2004). “A Model of Circumstantial Corruptibility. Police Quarterly. (New York: Sage publications) P160.

Woodland, D. (2015). Crime and Corruption at the Yard: Downfall of Scotland Yard. Barnsley: Pen $\&$ Sword Books. P VIII.

World Development Report. (2006).Equity and Development by world Bank P 48.

Young P.V. (1975).Scientific Social Survey and Research. New Delhi: Prentice-Hall of India. 